\title{
Implementasi Peraturan Walikota Binjai Nomor 23 Tahun 2019 Tentang Pembentukan Unit Pelaksanaan Teknis Daerah Bus Rapid Transit
}

\section{Implementation Of Binjai Mayor Regulation Number 23 Year 2019 Concerning The Establishment Of A Bus Rapid Transit Area Technical Implementation Unit}

\author{
Reza Fachrozi, Isnaini* \& Rudi Salam Sinaga \\ Pascasarjana Magister Administrasi Publik, Universitas Medan Area, Indonesia \\ Diterima: 09 Juni 2021; Disetujui: 15 Desember 2021; Dipublish: 01 Januari 2022
}

\begin{abstract}
Abstrak
Tujuan dari penelitian ini adalah untuk mengetahui dan menganalisis, bagaimana Implementasi kebijakan Walikota Binjai dalam hal meningkatkan kualitas dan mutu pelayanan publik khususnya pelayanan Transportasi kepada masyarakat Kota Binjai. Metode yang digunakan pada penelitian ini adalah kualitatif deskriptif dengan menggunakan teori Merille S. Grindle dimana ada beberapa variabel yang menentukan keefektifan implementasi kebijakan. Dari hasil penelitian dapat dilihat bahwa setelah penerapan Peraturan Walikota di Dinas Perhubungan Kota Binjai, terdapat perubahan dimana sebelumnya proses pengelolaan transportasi, yang selama ini di berada pada PD Angkutan Kota Binjai dengan menggunakan biaya angkut dan angkutan lainnya sekarang di alihkan ke Dinas Perhubungan untuk mengelolanya dengan tidak di pungut biaya sehingga dapat memudahkan masyarakat untuk melakukan aktifitas sehari hari dengan menggunakan trans Binjai.

Kata Kunci: Dinas Perhubungan; Implementasi; UPTD Trans Binjai.
\end{abstract}

\section{Abstract}

The purpose of this research is to find out and analyze, how the implementation of policies of the Mayor of Binjai in terms of improving the quality and quality of public services, especially transportation services to the people of Binjai City. The method used in this research is descriptive qualitative using the Merille S. Grindle theory where there are several variables that determine the effectiveness of policy implementation. From the results of the study it can be seen that after the implementation of the Mayor's Regulation at the Binjai City Transportation Agency, there was a change where previously the transportation management process, which had been in PD Angkutan Kota Binjai using transportation costs and other transportation, is now transferred to the Transportation Office to manage it with free of charge so that it can make it easier for people to carry out daily activities using Trans Binjai. Keywords: Department of Transportation; Implementation; UPTD Trans Binjai.

How to Cite: Fachrozi, R., Isnaini, \& Sinaga, R.S. (2022). Implementasi Peraturan Walikota Binjai Nomor 23 Tahun 2019 Tentang Pembentukan Unit Pelaksanaan Teknis Daerah Bus Rapid Transit Pada Dinas Perhubungan Kota Binjai. PERSPEKTIF, 11 (1): 151-159

*Corresponding author:

ISSN 2085-0328 (Print)

E-mail: isnaini@staff.uma.ac.id ISSN 2541-5913 (online) 


\section{PENDAHULUAN}

Wacana Pemerintah untuk merubah paradigma baru manajemen pemerintahan telah dilakukan di Indonesia dengan program Layanan Transportasi yang Smart dengan diterbitkannya Peraturan Pemerintah Nomor 23 tahun 2019. tentang Peempentukan Unit Pelaksanaan teknis Daerah Bus Rapid Transit yang pada intinya menjelaskan, Dinas Perhubungan senbagai pengelolaan Trans Binjai namun juga sebagai paradigma baru bagi manajemen pelayanan sektor publik. Pelayanan fasilitas publik khususnya pelayanan Transportasi di Indonesia masih belum memuaskan harapan publik, hal ini disebabkan pelayanan publik khususnya Transportasi di Indonesia masih identik dengan ketidak pastian baik dalam hal biaya, waktu dan prosedur. Sudah lama masyarakat mengeluhkan penyelenggaraan layanan publik yang dinilai sangat jauh dari harapan (Dwiyanto, 2018). Oleh karena itu, ini menjadi pekerjaan rumah bagi pemerintah untuk meningkatkan penyelenggaraan pelayanan publik lebih baik lagi

Sebagai salah satu contoh masih rendahnya mutu pelayanan Transportasi dapat dilihat di catatan Transportasi masal, pada tahun 2019, di bidang Transportasi terdapat tiga laporan yang terkait dengan layanan Trasnportasi, laporan terkait dengan layanan

Institusi Pemerintah diharapkan untuk melepaskan diri dari birokrasi lama, dengan mengajak organisasi dan pegawai agar lebih fleksibel, dan menetapkan tujuan, serta target organisasi secara lebih jelas sehingga memungkinkan pengukuran hasil (Hood dalam Saggaf dkk, 2018).

Penilaian hasil kinerja sebuah instansi baik keuangan maupun non-keuangan akan lebih mudah untuk dinilai kalau sebuah organisasi atau institusi tersebut memiliki tujuan dan sasaran yang jelas. Tujuan dan sasaran inilah yang menjadi tolak ukur sukses atau tidaknya pengelolaan sebuah institusi. Semua yang dicanangkan oleh pemerintah pada dasarnya untuk mewujudkan pola yang efektif dan efisien pada institusi-institusi yang ada.

\section{METODE PENELITIAN}

Dalam penelitian ini, peneliti akan menggunakan metodologi penelitian deskriptif kualitatif. Menurut Bogman dan Taylor yang dikutip Moleong (1993) didefinisikan sebagai prosedur penelitian yang menghasilkan data deskriptif berupa kata-kata tertulis/ lisan dari orang-orang dan perilaku yang dapat dicermati.

Penelitian ini akan membahas implementasi kebijakan dengan menggunakan teori yang disampaikan Merille S. Grindle bahwa sebuah Implementasi Kebijakan akan berhasil atau gagal dalam implementasinya dengan menentukan sebelumnya apa saja konten dan konteks kebijakan yang telah dibuat, yaitu konten atau isi kebijakan, dan konteks implementasi kebijakan

Sumber data dalam penelitian ini adalah dengan mengumpulkan data primer dan data sekunder. Teknik yang di lakukan dalam proses pengumpulan data adalah observasi, dokumentasi dan wawancara.

\section{HASIL DAN PEMBAHASAN}

Proses analisis implementasi kebijakan menurut Merille S. Grindle mencakup 2 variabel besar yakni isi kebijakan (content of policy) dan lingkungan implementasi (context of implementation) yang merupakan unsur untuk mempengaruhi kesuksesan dari implementasi suatu kebijakan. Oleh karena itu peneliti akan melakukan analisa dari hasil penelitian yang akan dilakukan seperti yang disajikan. Data yang telah diperoleh baik dari kegiatan dokumentasi, wawancara maupun observasi yang akan disampaikan dengan teknik analisis kualitatif dengan metode deskriptif dan tetap bertumpu pada hasil interpelasi data dan informasi yang sesuai dengan rumusan masalah dalam penelitian ini.

\section{Implementasi Peraturan Walikota Binjai Nomor 23 Tahun 2019 Tentang Pembentukan Unit Pelaksanaan Teknis Daerah Bus Rapit Transit pada Dinas Perhubungan Kota Binjai}

Dalam mengimplementasikan suatau kebijakan perlu ditentukan variabel- variabel yang terkait dalam proses pelaksanaaan suatu kebijakan tersebut. Berdasarkan variabel variabel tersebut, para pelaksana kebijakan akan mengetahui kesuksesan dan kegagalan dari sebuah kebijakan yang sudah diterapkan, sedang berlangsung atau belum diterapkan. Pada tahapan lainnya akan sangat membantu untuk penyempurnaan dan perbaikan atau evaluasi tahapan implementasi kebijakan dimasa yang datang. 
Isi Kebijakan (Content of Policy). Isi dari sebuah kebijakan merupakan hal yang paling penting untuk diperhatikan dalam membuat sebuah kebijakan, isi kebijakan harus dapat memenuhi kebutuhan kelompok sasaran dari sebuah kebijakan yang dibuat. Keberhasilan implementasi suatu kebijakan akan sangat tergantung dari isi kebijakan tersebut, karena kualitas implementasi kebijakan dinilai sukses dikarenakan telah melewati tahapan penetapan dan penentuan isi kebijakan sebelum suatu kebijakan dilaksanakan.

Teori implementasi kebijakan yang dikemukakan Merille S. Grindle juga menyebutkan bahwa isi kebijakan menjadi hal yang paling utama di tahap implementasiannya, dimana ia mengkatagorikan implementasi kebijakan dapat dilaksanakan jika isi kebijakannnya memiliki enam kriteria yang ia maksudkan yaitu kepentingan-kepentingan terkait, jenis manfaat yang diperoleh, perubahan yang diinginkan, letak pengambilan keputusan, pelaksana program dan sumber-sumber daya yang digunakan untuk melaksanakan kebijakan.

Implementasi Peraturan Walikota Binjai Nomor 23 Tahun 2019 Tentang Pembentukan Unit Pelaksanaan Teknis Daerah Bus Rapit Transit

Pada awal implementasi Implementasi Peraturan Walikota Binjai Nomor 23 Tahun 2019 Tentang Pembentukan Unit Pelaksanaan Teknis Daerah Bus Rapit Transit pada DinasPerhubungan Kota Binjai Kota Binjai, para implementor menghadapi berbagai tantangan. Dikarenakan kebijakan baru ini perlu sosialisasi yang memadai kepada seluruh kelompok kepentingan yang terkait dan berkepentingan dengan Dinas Perhubungan.

Berdasarkan hasil wawancara dengan informan kunci yaitu Kepala Dinas Perhubungan Kota Binjai sebagai penanggungjawab TransBinjai yaitu:

"Pada awalnya kepentingan membuat perencanaan program Trans Binjai ini dibuat untuk mewadahi Visi dan Misi Walikota pada waktu kampanye periode kedua yang kemudian dituangkan dalam Visi dan Misi Pembangunan Kota Binjai Periode Tahun 20162021.Terwujudnya Kota Cerdas Layak Huni dengan inovasi di bidang transportasi sebagai layanan masyarakat. (Informasi dari Kepala Dinas Perhubungan Kota Binjai wawancara di Ruang Rapat Kepala Dinas Perhubungan Kota Binjai pada tanggal 09 Nopember 2020, Transkrip wawancara Perubahan yang di inginkan tentang Pembentukan UPTD Trans Binjai).

Hal senada juga dikemukakan oleh informan lain yaitu kepala bidang Lalu lintas yang menyatakan bahwa :

"Perubahan yang ingin dicapai dengan adanya BRT ini adalah sebagai Penunjang Smart City, ingin juga membuat Transportasi yang Smart dan berteknologi canggih dan sebagai Transportasi masal yang pertama di Sumatera Utara yang menunjang Smart City dalam Transportasi yang berteknologi canggih, sehingga masyarakat dapat berinovasi dan pintar dalam menggunakan Trasnportasi yang berteknologi, dan mengurangi biaya pengeluaran masyarakat dalam segi ongkos yang dikeluarkan perharinya"(Informasi oleh Kepala Bidang Lalu Lintas pada Dinas Perhubungn Kota Binjai, di ruang kerjanya pada tanggal 23 Nopember 2020, Transkrip wawancara Perubahan yang di inginkan tentang Pembentukan UPTD Trans Binjai).

Hal ini dikuatkan oleh Perda No. 23 Tahun 2019 bahwa pembentukan unit pelaksanaan teknis busrapid transit pada dinas perhubungan kota binjai yang berdasarkan kaidah-kaidah manajemen yang baik dalam rangka pemberian layanan yang bermutu dan manajemen berkesinambungan. Hal senada juga dinyatakan oleh Van Meter dan Van Horn (dalam Winarno, 2002) bahwa untuk mencapai suatu tujuan harus ditetapkan dalam satu keputusan kebijakan sehingga dapat memberikan perubahan yang diinginkan.

\section{Manfaat Implementasi Peraturan walikota Binjai Nomor 23 Tahun 2019 tentang Pembentukan Unit Pelaksanaan Teknis Bus Rapid Transit}

Variabel kedua yang menentukan keberhasilan suatu kebijakan atau program dilaksanakan pada model implementasi kebijakan yang disebutkan oleh Merille S. Grindle, adalah indikator jenis manfaat yang bisa diperoleh. Dari sebuah kebijakan harus bisa ditunjukkan jenis - jenis manfaat yang dapat diraih sebagai efek positif apabila suatu kebijakan tersebut diimplementasikan. 
Hal ini seperti hasil wawancara dengan Kepala Dinas Perhubungan sebagai informan kunci, yaitu:

"Sebenarnya Walikota kita sangat cerdas untuk komit mengeluarkan PERWA ini, namun untuk keberlanjutan dan kesinambungan program Trans Binjai mestinya Pimpinan SKPD harus cerdas juga untuk mengimbangi visi dari Walikota menyampaikan apa yang bisa dilakukan di SKPDnya masing-masing programprogram yang mendukung Smart City, tidak melulu tunggu instruksi dari Walikota baru dibuat aplikasi sesuai tupoksi, masing-masing Kepala SKPD harus kreatif, berkompeten mengembangkan Teknologi, mampu menggali hal-hal apa yang perlu untuk meningkat ekonomi masyarakat sesuai dengan teknologi, tidak monoton". Informasi dari Kepala Dinas Perhubungan Kota Binjai dan Pengguna Trans Binjai hasil wawancara di Ruang Rapat Beliau Tanggal 09 Nopember 2020,, Transkrip wawancara tentang karakteristik lembaga dan rezim yang berkuasa).

Hal ini juga dibenarkan informan lain yaitu kepala bagian angkutan dan prasarana yang menyatakan bahwa :

"Bus rapiD transit ini dapat menjadikan Kota Binjai sebagai Kota yang Berinovasi dan menjadi Kota yang Smart, dan mempunyai Transportasi yang smart, denganadanya UPTD Bus Rapid Transit maka pengelolaan Bus Trans Binjai ini semakin terkodinir dengan pengelolaan dan perbaikan pada Bus tersebut"(informasi ini didapat oleh Kepala Bidang Angkutan dan Prasarana Dinas Perhubungan Kota Binjai pada tanggal 30 Nopember 2020 di ruang kerjanya, Transkip wawancara Perubahan yang di inginkan tentang Pembentukan UPTD Trans Binjai).

Di samping hasil wawancara peneliti dengan informan, peneliti juga telah melakukan observasi dan dokumentasi dilapangan, meskipun belum semua ketentuan mengenai Trans Binjai dapat dilaksanakan, namun dengan keadaan yang sekarang sudah dapat memberi manfaat kepada pihak - pihak yang terkait langsung seperti Bagian Lalulintas dan Bagian angkutan dan Program. Dengan fleksibilitas yang menjadi filosofi utama dari Trans Binjai, proses perancanaan kegiatan, penganggaran, pengelolaan dan monitoring laporan dapat lebih dengan mudah dilaksanakan. Seperti yang diungkapkan juga oleh Charles 0 Jones (dalam Arif Rohman 2009:
101-102) bahwa Implementasi program merupakan langkah - langkah pelaksanaan kegiatan dalam upaya mencapai tujuan dari program itu sendiri.

\section{Keterkaitan Implementasi Peraturan walikota Binjai Nomor 23 Tahun 2019 tentang Pembentukan Unit Pelaksanaan Teknis Bus Rapid Transit dengan Derajat Perubahan yang Ingin Dicapai.}

Dengan diterapkannya Trans Binjai ini, diharapkan dapat menunjukkan suatu perubahan yang sebelumnya masyarakat menaiki trasnportasi masal biasa dan sekarang sudah di sediakannya Trans Binjai dengan tanpa di pungut biaya, sehingga pada akhirnya dapat meningkatkan mutu pelayanan transportasi.

Hal ini juga sesuai dengan apa yang diungkapkan oleh Kepala Dinas Perhubungan yang menjadi informan sewaktu peneliti wawancarai, yaitu pernyataan tentang derajat perubahan yang diinginkan dalam implementasi Perwal tentang Trasn Binjai sebagai berikut:

"Dengan adanya Bus BRT ini dapat dirasakan sebagian masyarakat yang mempunyai anak yang masih sekolah, dengan adanya Bus BRT tersbut dapat mengurangi biaya beban dari satu keluarga yang anak nya masi duduk di sekolah dasar,sekolah menengah pertama, maupun sekolah menengah atas, sehingga beban untuk pengeluaran ongkos yang biasanya besar kini berkurang dengan adanya Bus BRT ini"(Informasi dari Kabid Angkutan, Transkip wawancara Perubahan yang di inginkan tentang Pembentukan UPTD Trans Binjai).

Akan tetapi, belum semua perubahan yang diharapkan dengan adanya Perwal tersebut dapat tercapai. Hal ini yang disebutkan informan lain yang menyatakan bahwa :

"Dengan Pembentukan UPTD Bus RapiD Transit dianggap sangat membantu para ibu rumah tangga dalam membantu mengurangi biaya atau beban dalam ongkos angkutan yang selama ini menjadi momok bagi para ibu rumahtangga dan juga sebagai Icon Kota Binjai dalam Bentuk Transportasi sehingga dapat menjadi daya tarik Kota Lain Untuk Menaiki dan Mengelilingi Kota Binjai dengan Menaiki Trasn Binjai Tersebut" "Informasi dari Camat Binjai Utara di acara Persiapan Penyambutan Tahun Baru 2021 di Jl.Soedirman pada tanggal 21 
Desember 2020, Transkip wawancara Perubahan yang di inginkan tentang Pembentukan UPTD Trans Binjai).

Berdasarkan hasil wawancara yang dilakukan oleh peneliti di atas, peneliti bisa melihat bahwa selama ini perubahan yang ingin dicapai dengan implementasi PERWAL TRANS BINJAI ialah agar proses pengelolaan keuangan dapat lebih hemat dan efesien dan fleksibel sehingga bermuara pada peningkatan mutu pelayanan kepada masyarakat yang lebih baik.

Letak Pengambilan Keputusan dalam Implementasi Peraturan walikota Binjai Nomor 23 Tahun 2019 tentang Pembentukan Unit Pelaksanaan Teknis Bus Rapid Transit dengan Derajat Perubahan yang Ingin Dicapai.

Pengambilan keputusan sangat berkaitan erat dengan pihak - pihak berkepentingan dalam implementasi suatu kebijakan, dimana setiap keputusan yang diambil dalam menjalankan suatu kebijakan dan program harus sesuai dengan ketentuan dan peraturan yang telah diputuskan. Sehingga apabila keputusan yang diambil sudah tepat maka para implementor dilapangan tidak akan kesulitan dalam melaksanakan keputusan tersebut dan tidak menjadi masalah hukum dikemudian hari.

Pernyataan oleh informan kunci diwawancarai peneliti terkait letak pengambilan keputusan, sebagai berikut:

"Setelah mendapat persetujuan dari Bapak Walikota, segera diterbitkan Peraturan walikota tentan Pembentukan Unit Pelaksanaan teknis daerah Bus Rapid Trasnit Pada Dinas Perhubungan Kota Binjai.

Dengan demikian, dari hasil wawancara di atas dapat dilihat bahwa Dinas Perhubungan Kota Binjai sebagai pengambil keputusan dalam pelaksanaan dan pengambilan kebijakan. Hal ini sesuai dengan apa yang dikemukakan Thomas R. Dye (dalam Subarsono 2009:2) apapun yang dipilih oleh pemerintah untuk melakukan atau tidak melakukan (public policy whatever government choose to do or not to do). Artinya, segala sesuatu yang dilakukan atau tidak dilakukan tergantung dari keputusan pemerintah.

\section{Pelaksana Program dalam Implementasi Pelaksanaan Teknis Daerah Bus Rapid Transit}

Keberhasilan sebuah implementasi kebijakan menurut Merille S. Grindle melalui indikator pelaksana program, hal ini dikarenakan bahwa pelaksanaan suatu kebijakan merupakan tolak ukur dan faktor penentu kesuksesan implementasi suatu kebijakan bisa berhasil atau gagal dimplementasikan. Pelaksana program yang ditunjuk harusnya kompeten dan kapabel yang ditentukan dan ditetapkan di awal pembuatan kebijakan. Hal ini dapat diartikan, bahwa pelaksana program inilah yang nantinya akan memberi dan menyediakan pelayanan bagi masyarakat di dalam suatu program yang telah dibuat.

Informan yang diwawancarai oleh peneliti yaitu Direktur RSUD Dr. RM. Djoelham Binjai berkaitan dengan pelaksana program:

"Dalam implementasi Trans Binjai di Dinas Perhubungan pelaksana utama kebijakan ini adalah bagian Angkutn dan Prasarana program dibawah koordinasi Kepala Unit Teknis Daerah ikut membantu dalam implementasi Perwal 23 Tentang Pembentukan UPTD Trans Binjai. (Informasi dari Kepala Dinas Perhubungan Kota Binjai)

Jadi dalam hal ini dapat disimpulkan bahwa pelaksana program suatu kebijakan harus saling bekerjasama dalam mensukseskan implementasi suatu kebijakan. Baik yang terlibat secara langsung mauun tidak langsung. Stakeholders kebijakan terdiri dari aktor aktor kebijakan yang berperan sejak proses formulasi, implementasi dan evaluasi kebijakan. Para aktor dapat dibedakan menjadi aktor internal birokrasi dan aktor eksternal birokrasi (Anderson dalam Madani, 2011)

\section{Keterkaitan Implementasi Pelaksanaan Teknis Daerah Bus Rapid Transit}

Dari hasil observasi peneliti di lapangan apanila dilihat dari sisi sumber dana, Dinas Perhubungan Kota Binjai menyiapkan anggaran untuk persiapan implementasi Perwal Trans Binjai. Anggaran yang disiapkan diperuntukkan untuk panitia yang dibentuk agar dapat bekerja secara optimal. Selain anggaran untuk keperluan internal tim yang dibentuk seperti alat tulis kantor, perlengkapan dan peralatan kantor, honorarium tim, juga disiapkan anggaran Operasional dan Perbaikan 
maupun unag Minyak Bus Trans Binjai Selanjutnya peneliti melakukan wawancara dengan informan kunci terkait sumber daya yang ada dalam implementasi Peaturan Walikota Tentang Pelaksana Teknis Daerah Bus Rapid Transit Pada Dinas Perhuungan Kota Binjai, yaitu:

"Dari sisi sumber daya, terutama sumber daya manusia dalam implementasi Peaturan Walikota Tentang Pelaksana Teknis Daerah Bus Rapid Transit Pada Dinas Perhuungan Kota Binjai. Selain membentuk tim yang diisi oleh orang - orang dari internal rumah sakit yang dianggap kompeten, kita juga memerlukan teknisi tersendiri untuk perbaikan Bus tersebut sehingga dapat mengurangi biaya ongkos Teknisi dan biaya perbaikan lainnya.

Informan lain yang diwawancarai peneliti juga mengungkapkan perihal sumber daya yang ada pada saat proses implementasi implementasi Peaturan Walikota Tentang Pelaksana Teknis Daerah Bus Rapid Transit Pada Dinas Perhuungan Kota Binjai, yaitu:

"Dengan adanya tim teknisi, maka orang orang yang ada dalam tim tersebut merupakan orang - orang yang dianggap mampu dan memiliki kompetensi. Tim tersebut terdiri dari Kepala Bengkel dan Kernet. Hal ini dikarenakan lebih banyak hal - hal yang perlu dipersiapkan dari tim, kita juga mempersiapkan anggaran yang memadai untuk menopang segala kebutuhan tim yang bertugas mempersiapkan implementasi ini.". (Informasi dari Kepala Perbengkelan Bus Trans).

Konteks Kebijakan (Context Of Policy). Konteks kebijakan juga merupakan bagian penting yang perlu diperhatikan selain dari isi kebijakan yang terkait dengan pelaksanaan kebijakan, pada pengimplementasian kebijakan sebaiknya dapat mengetahui variabel - variabel yang mengakibatkan suatu kebijakan berhasil atau gagal dimplementasikan. Konteks kebijakan merupakan variabel yang bisa mempengaruhi keberhasilan suatu implementasi kebijakan termasuk juga pada implementasi Peaturan Walikota Tentang Pelaksana Teknis Daerah Bus Rapid Transit Pada Dinas Perhuungan Kota Binjai Berikut ini adalah pemaparan mengenai konteks kebijakan pada pelaksanaan implementasi Peaturan Walikota Tentang Pelaksana Teknis Daerah Bus Rapid Transit Pada Dinas Perhuungan Kota Binjai.
Keterkaitan Implementasi implementasi Peaturan Walikota Tentang Pelaksana Teknis Daerah Bus Rapid Transit dengan Kekuasaan, Kepentingan-Kepentingan dan Program atau Strategi dari Aktor yang Terlibat.

Berbicara mengenai strategi, Kepala Dinas selaku penanggungjawab implementasi implementasi Peaturan Walikota Tentang Pelaksana Teknis Daerah Bus Rapid Transit Pada Dinas Perhuungan Kota Binjai mengambil langkah - langkah strategis guna mempercepat pelaksanaan implementasi Peaturan Walikota Tentang Pelaksana Teknis Daerah Bus Rapid Transit Pada Dinas Perhuungan Kota Binjai. Hal ini seperti yang diungkapkan pada saat wawancara mengenai strategi dan aktor yang terlibat, yaitu:

"Setelah dibentuk tim Pelaksana Teknis Daerah Bus Rapid Transit Pada Dinas Perhuungan Kota Binjai, kita langsung mengadakan rapat dan menbagi tim tersebut menjadi kelompok - kelompok kecil yang bertanggungjawab menyelesaikan tugasnya masing - masing. Ada yang mengerjakan Rencana Strategi Bisnis (RSB), ada yang mengerjakan Standart Pelayanan Minimal (SPM), ada yang mengerjakan pola tata kelola. Jadi kelompok - kelompok kecil ini diberi target untuk menyelesaikan dokumen yang menjadi tanggungjawabnya. Dengan demikian kita bisa mempercepat proses penyelesaian persyaratan yang dibutuhkan sesuai target yang telah direncanakan. Setelah penilaian yang dilakukan oleh tim penilai yang diketuai oleh bapak Sekretaris Daerah yang hasilnya penilaiannya kita dianggap layak (Informasi dari DKepala Dinas Perhubungan Kota Binjai)

Hal ini juga dikuatkan oleh informan lainnya seperti hasil wawancara yang dilakukan peneliti tentang bagaimana tanggapan dan strategi yang dilakukan dalam menjalankan program implementasi Peaturan Walikota Tentang Pelaksana Teknis Daerah Bus Rapid Transit Pada Dinas Perhuungan Kota Binjai, yaitu:

"Setelah penetapan implementasi Peaturan Walikota Tentang Pelaksana Teknis Daerah Bus Rapid Transit Pada Dinas Perhuungan Kota Binjai dengan dikeluarkannya Perwal Tersebut, kita langsung bergerak mepersiapkan dokumen - dokumen pendukung lainnya dan seiiring dengan itu kita juga mengadakan sosialisasi dengan pihak - pihak 
terkait dengan implementasi implementasi Peaturan Walikota Tentang Pelaksana Teknis Daerah Bus Rapid Transit Pada Dinas Perhuungan Kota Binjai baik di internal juga dengan pihak eksternal. Diawal penerapannya memang ditemui beberapa kendala, terutama mengenai penganggaran dan pelaporan keuangan, hal ini merupakan sesuatu yang biasa terjadi karena program ini adalah program baru yang perlu pemahaman dan sosialisasi yang lebih optimal lagi". ((Informasi dari Kepala Bagian Angkutan dan Prasarana)

Dengan penerapan yang merupakan hal baru dalam pola pengeloaan Trans Binaji, tentunya dalam pelaksanaannya menemui berbagai kendala. Oleh karena itu dibutuhkan strategi - strategi yang baik sehingga kendala yang ada dapat diminimalisir. Disinilah dibutuhkan aktor - aktor pelaksana kebijakan yang handal dalam melaksanakan strategi yang direncanakan. Dalam pemilihan aktor - aktor yang berperan menjalankan strategi pelaksanaan kebijakan tersebut. Menurut Jones (dalam Silalahi , 1992:150) dalam membahas implementasi kebijakan terdapat aktor yang terlibat, yaitu : Beberapa orang diluar birokrat - birokrat yang mungkin terlibat dalam aktivitas - aktivitas implementasi suatu kebijakan.

\section{Keterkaitan Implementasi implementasi Peaturan Walikota Tentang Pelaksana Teknis Daerah Bus Rapid Transit dengan Karakteristik Lembaga dan Rezim yang Berkuasa}

Dalam implementasi suatu kebijakan, karakteristik lembaga dan rezim yang berkuasa juga ikut berperan. Pada bagian ini peneliti akan membahas bagaimana situasi dan kondisi pihak-pihak yang terkait. Apakah telah sesuai dengan tugas pokok dan fungsinya dalam melaksanakan tugasnya. Dengan demikian dapat kita lihat sejauh mana peranan rezim yang sedang berkuasa dan karakteristik lembaga dalam implementasi implementasi Peaturan Walikota Tentang Pelaksana Teknis Daerah Bus Rapid Transit Pada Dinas Perhuungan Kota Binjai.

Hal tersebut seperti yang dikemukakan pada saat wawancara yang dilakukan kepada direktur sebagai berikut:

"sebagai pimpinan saya yang bertanggungjawab dalam implementasi Peaturan Walikota Tentang Pelaksana Teknis Daerah Bus Rapid Transit Pada Dinas
Perhuungan Kota Binjai ini. Hal ini juga sesuai dengan Tugas Pokok dan Fungsi Dinas Perhubungan memiliki tugas pokok membantu Walikota dalam melaksanakan penyusunan dan pelaksanaan kebijakan daerah di bidang pelayanan Transportasi. Fungsi Dinas Perhubungan adalah perumusan kebijakan teknis bidang pelayanan Transportasi, pemberian dukungan atas penyelenggaraan Pemerintah Daerah di bidang pelayanan ransportasi, dan pelaksanaan tugas lain yang diberikan oleh Walikota sesuai tugas dan fungsinya. Hal ini juga sesuai dengan arahan dari Bapak walikota bahwa beliau akan selalu mendukung apapun program yang ingin dilaksanakan oleh Dinas Perhubungan yang bertujuan untuk meningkatkan mutu pelayanan. Oleh karena itu dengan ditetapkan Dinas Perhubungan sebagai Pengelola Trasn Binjai, kita berupaya sekuat tenaga melaksanakan kebijakan tersebut untuk mencapai tujuan bersama yaitu meningkatkan mutu pelayanan Transportasi milik Pemerintah Kota Binjai ini". (Informasi Kepala Dina PErhubungan Kota Binjai)

Kepala Dinas Perhubungan sebagaimana yang telah diamanahkan oleh Bapak Walikota Binjai harus terus mengkoordinir dan memimpin jalannya program implementasi Peaturan Walikota Tentang Pelaksana Teknis Daerah Bus Rapid Transit Pada Dinas Perhuungan Kota Binjai. Komitmen dari Bapak Walikota dalam mendukung pelaksanaan Trans Binjai juga sangat mendukung implementasi implementasi Peaturan Walikota Tentang Pelaksana Teknis Daerah Bus Rapid Transit Pada Dinas Perhuungan Kota Binjai. Walikota Binjai betul - betul mendukung program ini bukan hanya dari sisi anggaran, juga sering turun langsung memantau implementasi Peaturan Walikota Tentang Pelaksana Teknis Daerah Bus Rapid Transit Pada Dinas Perhuungan Kota Binjai.

\section{Keterkaitan implementasi Peaturan Walikota Tentang Pelaksana Teknis Daerah Bus Rapid Transit dengan Tingkat Kepatuhan dan Adanya Respon dari Para Pelaksana}

Pada variabel kebijakan ini, variabel tingkat kepatuhan dan respon dari para implementor suatu kebijakan adalah hal yang juga penting dengan menentukan siapa pelaksananya, karena tingkat kepatuhan dan 
adanya daya tanggap dari para pelaksana program adalah bentuk dukungan yang tentunya juga mempengaruhi keberhasilan implementasi suatu kebijakan.

Dalam hasil wawancara peneliti dengan salah satu informan, dikemukakan perihal kepatuhan dan respon dari pelaksana yaitu :

"Pada awal penerapan Trans Binjai, tentunya belum sepenuhnya dapat berjalan seperti yang diharapkan. Keinginan kita, setiap pihak yang memiliki tanggungjawab dalam implementasi kebijakan ini dapat bersinergi dalam rangka mempercepat penerapannya dilapangan. Namun mungkin karena Trans Binjai ini identik hanya dengan pengelolaan Transportasi.". (Informasi Kepala Dinas Perhubungan)

\section{SIMPULAN}

Pada awal persiapan implementasi implementasi Peaturan Walikota Tentang Pelaksana Teknis Daerah Bus Rapid Transit Pada Dinas Perhuungan Kota Binjai, tim persiapan yang dibentuk menghadapi berbagai tantangan. Dikarenakan Trans Binjai ini merupakan kebijakan baru ini perlu sosialisasi yang memadai kepada seluruh kelompok kepentingan yang terkait dan berkepentingan dengan Dians Perhubungan. Pemerintah Kota Binjai Harus dapat merubah pola fikir masyarakat untuk menggunakan Trasn Binjai dengan menggunakan pendekatan kepada masyarakat dengan melalui mengenalkan bahwa Trans Binjai sangat efektif dan efesien sebagai alternative di bidang transportasi, dan Pemerintah Kota Binjai Membuat Rute atau Koridor yang lebih mendasan dalam arti jangan di jalan utama saja yang di lalui oleh Trans Binjai Tersebut dan juga Pelayanan dan Ketepatan Waktu Harus di tertipkan lagi sehingga masyarakat tidak kecewa dengan menaiki Trans Binjai Tesebut,dan Juga Pemerintah Kota Binjai Mempromosikan Trans Binjai Tersebut Hingga Melibatkan Lurah dan Kepling di setiap Kecamtan yang ada, dan diharapkan pemerintah harus dapat bekerja sama dengan pihak - pihak yang terkait dalam bidang Transportasi. Adapun saran yang dapat peneliti berikan yaitu meliputi berbagai aspek yang menunjang untuk keberhasilan dari Implementasi Peraturan Walikota Nomor 23 Tahun 2019 tentang Pembentuka Unit Pelaksana Teknis Daerah Bus Rapit Transit Pada Dinas Perhubungan Kota Binjai.

\section{DAFTAR PUSTAKA}

Akib, H. (2009). Dasar-Dasar Teori Organisasi. Medan: Universitas Negeri Medan.

Angkutan Bus Cepat Transportasi Berkelanjutan : Panduan Bagi Pembuat Kebijakan di Kota Kota Berkembang.Terjemahan Miftahuljannah.Tersedian:

http://www.bmz.de Diakses Sabtu 23 April 2016.

Badan Litbang Departemen Perhubungan 2004.: Kajian Penyelenggaraan Busway,Jakarta

BRT Seharusnya menjangkau Perumahan, Tersedia: http://jateng.tribunnews.com. Diakses: Sabtu 23 April 2016.

Dwiyanto, A. (2018). Manajemen Pelayanan Publik: Peduli Inklusif Dan Kolaborasi. Yogyakarta : Gajah Mada University Press.

Fachrozi, R., Isnaini, I., \& Sinaga, R. (2021). Implementasi Peraturan Walikota Binjai Nomor 23 Tahun 2019 Tentang Pembentukan Unit Pelaksanaan Teknis Daerah Bus Rapid Transit Pada Dinas Perhubungan Kota Binjai. Strukturasi: Jurnal Ilmiah Magister Administrasi Publik, 3(1), 3043.

doi:https://doi.org/10.31289/strukturasi.v3 i1.522

Fahmi, R. Kadir, A. \& Batubara, B.M. (2019). Implementasi Peraturan Walikota Medan Nomor 8 Tahun 2017 Tentang Pajak Restoran Di Kota Medan (Studi Kasus Di Badan Pengelolah Pajak Dan Retribusi Daerah Kota Medan). Jurnal Ilmu Pemerintahan, Administrasi Publik dan Ilmu Komunikasi (JIPIKOM), 1(2) 2019: 115-125,

Instruksi Presiden Nomor 3 Tahun 2003 tentang Kebijakan dan Strategi Nasional Pengembangan e-Government.

Instruksi Presiden Nomor 3 Tahun 2003 tentang Kebijakan dan Strategi Nasional Pengembangan e-Government.

Kementerian Perhubungan Republik Indonesia.2010 :Trans Semarang: Masih Banyak Hambatan.Tersedia: http://m.dephub.go.id. Diakes Sabtu, 23 April 2016.

Madani, M. (2011). Dimensi interaksi aktor dalam proses perumusan kebijakan publik. Jakarta: Graha Ilmu.

Moleong, L.J. (2007). Metodologi Penelitian Kualitatif. Bandung: PT. Remaja Rosdakarya Offset.

Nasution, A., Mardiana, S., \& Isnaini, I. (2019). Implementasi Peraturan Walikota Binjai Nomor 47 Tahun 2017 tentang Sistem dan Prosedur Pemungutan Pajak Bumi dan Bangunan Perdesaan dan Perkotaan dan Kaitannya dengan Intensifikasi Penerimaan PBB P2 di Kota Binjai. Strukturasi: Jurnal 
Ilmiah Magister Administrasi Publik, 1(1), 5264

Peraturan Pemerintah Nomor 10 Tahun 1986 Tentang Perubahan Batas Wilayah Kotamadya Daerah Tingkat II Binjai.

Peraturan Walikota Nomor 23 Tahun 2019 tentang Pembentukan Unit Pelaksana Teknis Daerah Bus Rapt Transid Pada Dinas Perhubungan Kota Binjai.

Rencana pembangunan Jangka Menengah Daerah Tahun 2016-2021 Kota Binjai.

Saggaf, S., (2018), Reformasi Publik di Negara Berkembang. Makassar: CV. Sah Media

Subarsono, A.G. (2005). Analisis Kebijakan Publik. Yogyakarta: Pustaka Pelajar.

Subarsono, AG. (2009). Analisis Kebijakan Publik, Konsep, Teori dan Aplikasi. Jakarta. Pustaka Pelajar.

Sugiyono, (2012). Memahami Penelitian Kualitatif. Bandung: CV. Alfabeta.

Terminal BRT Dikelola Terpisah. Tersedia: dalam http://koran-sindo.com. Diakses Sabtu, 23 April 2016.

Trans Semarang: Masih Banyak Hambatan.Tersedia: http://m.dephub.go.id. Diakes Sabtu, 23 April 2016.

Trans Semarang: Masih Banyak Hambatan.Tersedia: http://m.dephub.go.id. Diakes Sabtu, 23 April 2016.

Udang - undang Nomor 23 Tahun 2014 Tentang Pemerintahan Daerah

Undang - undang Nomor 22 Tahun 2009 Tentang Lalu Lintas dan Angkutan Jalan.
Undang - undang Nomor 25 Tahun 2009 Tentang Pelayanan Publik.

Undang - undang Nomor 9 tahun 1956 Tentang Pembentukan Daerah Otonom kota kecil dalam Lingkungan Daerah Provinsi Sumatera Utara.

Undang - undang Republik Indonesia Nomor 22 Tahun 2009 Tentang Lalu Lintas dan Angkutan Jalan Beserta Peratuan Pelaksanaannya. Direktorat Jenderal Perhubungan Darat. Jakarta: Departemen Perhubungan.

Undang-Undang, Dokumen, Lembaga dan Peraturan:

Undang-Undang, Dokumen, Lembaga dan Peraturan: Waluyo, I. (2011). BLU Sebuah Pola Baru dalam Pengelolaan Keuangan Disatuan Kerja Pemerintah, Jurnal Pendidikan Akuntansi Indonesia IX No. 2.

Waluyo. (2002). Manajemen publik: konsep, aplikasi, dan implementasinya dalam pelaksanaan otonomi daerah. Indonesia: Mandar Maju.

Winarno, B. (2002). Teori dan Proses Kebijakan Publik. Yogyakarta: Mediapressindo.

Winarno, B. (2004). Implementasi konsep "Reinventing Government" dalam pelaksanaan Otonomi Daerah, FIA UPN Veteran, Surabaya, Jawa Timur.

Winarno, B., Ismawan, I. (2002). Teori dan proses kebijakan publik. Indonesia: Media Pressindo. 